\title{
The Argonaute protein family
} Julia Höck and Gunter Meister

\author{
Address: Center for Integrated Protein Science Munich (CIPSM), Laboratory of RNA Biology, Max Planck Institute of Biochemistry, Am \\ Klopferspitz, 82152 Martinsried, Germany.
}

Correspondence: Gunter Meister. Email: meister@biochem.mpg.de

Published: 26 February 2008

Genome Biology 2008, 9:210 (doi:10.1 186/gb-2008-9-2-210)

The electronic version of this article is the complete one and can be found online at http://genomebiology.com/2008/9/2/210

(c) 2008 BioMed Central Ltd

\section{Summary}

\begin{abstract}
Argonaute proteins were first discovered genetically, and extensive research in the past few years has revealed that members of the Argonaute protein family are key players in gene-silencing pathways guided by small RNAs. Small RNAs such as short interfering RNAs (siRNAs), microRNAs (miRNAs) or Piwi-interacting RNAs (piRNAs) are anchored into specific binding pockets and guide Argonaute proteins to target mRNA molecules for silencing or destruction. Various classes of small RNAs and Argonaute proteins are found in all higher eukaryotes and have important functions in processes as diverse as embryonic development, cell differentiation and transposon silencing. Argonaute proteins are evolutionarily conserved and can be phylogenetically subdivided into the Ago subfamily and the Piwi subfamily. Ago proteins are ubiquitously expressed and bind to siRNAs or miRNAs to guide post-transcriptional gene silencing either by destabilization of the mRNA or by translational repression. The expression of Piwi proteins is mostly restricted to the germ line and Piwi proteins associate with piRNAs to facilitate silencing of mobile genetic elements. Although various aspects of Argonaute function have been identified, many Argonaute proteins are still poorly characterized. Therefore, it is very likely that as yet unknown functions of the Argonaute protein family will be elucidated in the future.
\end{abstract}

\section{Gene organization and evolutionary history}

The Argonaute protein family was first identified in plants, and members are defined by the presence of PAZ (PiwiArgonaute-Zwille) and PIWI domains [1]. Argonaute proteins are highly conserved between species and many organisms encode multiple members of the family (Table 1). Numbers of Argonaute genes range from 1 in the fission yeast Schizosaccharomyces pombe to 27 in the nematode worm Caenorhabditis elegans. In mammals there are eight Argonaute genes [2,3]. The Argonaute protein family can be divided into the Ago subfamily and the Piwi subfamily (Figure 1) $[2,4,5]$. In most organisms investigated so far, which include Drosophila, the zebrafish and the mouse, the expression of Piwi proteins is restricted to the germ line, where they bind Piwi-interacting proteins (piRNAs). In contrast, Ago proteins are ubiquitously expressed in many organisms. Human Ago1, Ago3 and Ago4 genes are clustered on chromosome 1, whereas the Ago2 gene is located on chromosome 8 . Whether or not this clustering indicates that the proteins have similar functions in human cells has not been determined so far. The human Piwi subfamily comprises HIWI1, HIWI2, HIWI3 and HILI; they are encoded by genes on chromosomes 12, 11, 22 and 8, respectively.

The sole Ago protein in S. pombe is involved in the establishment of heterochromatin and the silencing of transcription of specific genomic regions. It is therefore tempting to speculate that transcriptional silencing appeared earlier in evolution than post-transcriptional silencing processes. It has, however, been shown that the single $S$. pombe Ago can also guide post-transcriptional gene silencing when provided with an artificial reporter plasmid [6]. Natural targets of post-transcriptional silencing in $S$. pombe have not yet been reported. 
Table I

\begin{tabular}{lcc} 
Number of Argonaute family genes in different species & \\
\hline Species & Number of genes & Reference \\
\hline Homo sapiens & 8 & {$[80]$} \\
Rattus norvegicus & 8 & {$[2]$} \\
Mus musculus & 8 & {$[2]$} \\
Drosophila melanogaster & 5 & {$[81]$} \\
Caenorhabditis elegans & 27 & {$[82]$} \\
Arabidopsis thaliana & 10 & {$[83]$} \\
Schizosaccharomyces pombe & 1 & {$[2]$} \\
Neurospora crassa & 2 & {$[2]$} \\
\hline
\end{tabular}

\section{Characteristic structural features}

All Argonaute proteins share two main structural features: the PAZ domain and the PIWI domain. Crystallization of a complete Argonaute protein from a higher organism has not yet been successful. Consequently, only isolated domains and archaeal full-length Argonaute proteins have been analyzed structurally by X-ray crystallography and by nuclear magnetic resonance (NMR) spectroscopy (Figure 2a). Studies on isolated PAZ domains from different organisms revealed that this domain contains a specific binding pocket that anchors the characteristic twonucleotide 3' overhang that results from digestion of RNAs by RNase III (a step in the processing of small RNAs) [7-11]. PIWI domains show extensive homology to RNase $\mathrm{H}$ [12-16]. Indeed, biochemical in vitro studies of Argonaute proteins from Arabidopsis thaliana, D. melanogaster and various

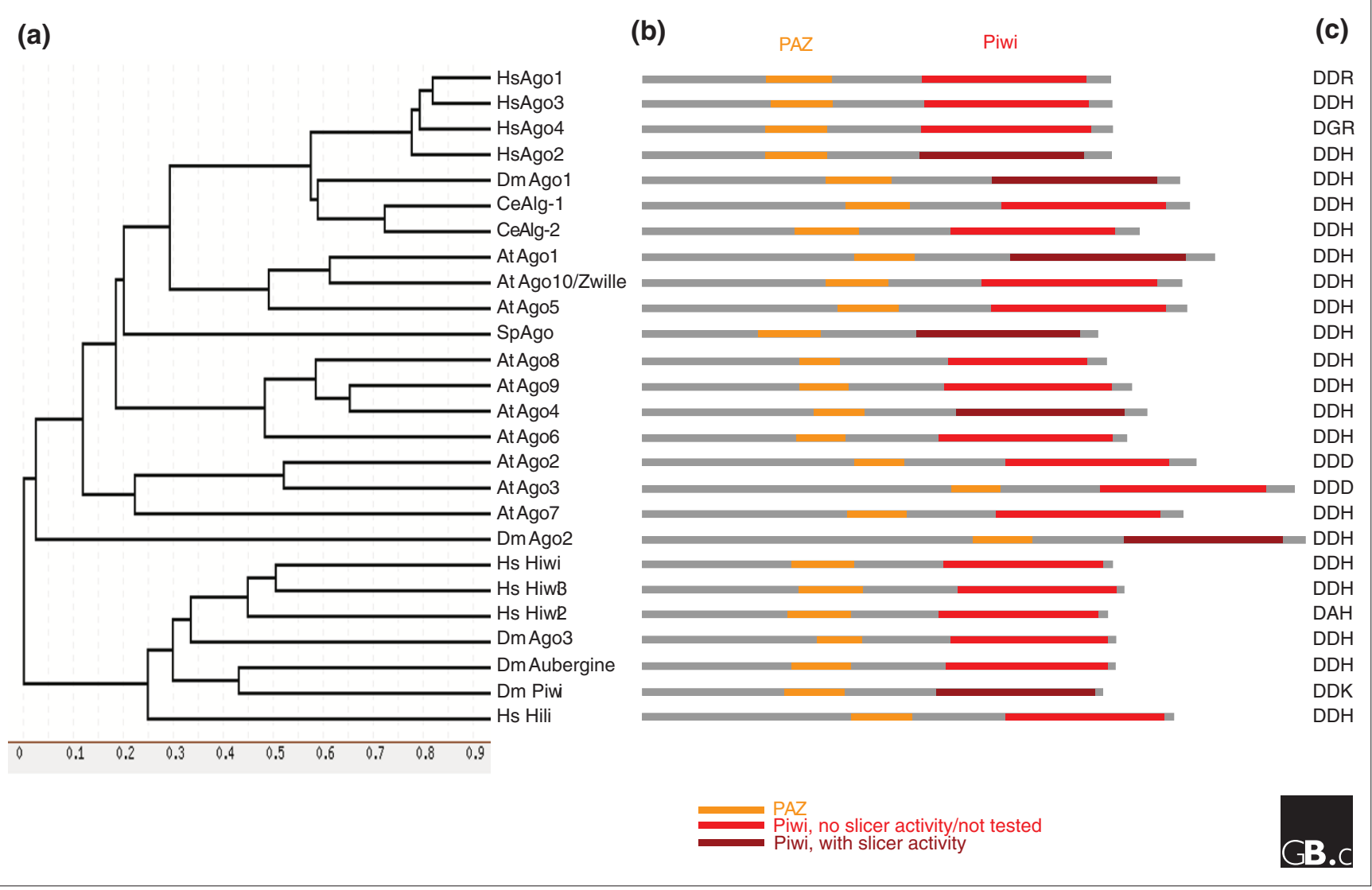

Figure I

Phylogenetic conservation of Argonaute proteins in various organisms. (a) Phylogenetic tree of Argonaute proteins based on the protein sequence. Alignments of protein sequences were made with ClustalW and the tree built with TreeTop. (b) The corresponding domain organizations of the proteins listed in the tree, showing the PAZ (orange) and PIWI (red) domains. PIWI domains of slicer-active Ago proteins are in dark red; PIWI domains of inactive Ago proteins are in light red. (c) Catalytic residues of the PIWI domain in single-letter amino-acid code. D, aspartic acid; G, glycine; $H$, histidine; K, lysine. The sequences used in the alignment are Homo sapiens (Hs) Agol (NP_03633I), Ago2 (NP_036286), Ago3 (NP_079l28), Ago4 (NP_060099), Hili (NP_060538), Hiwi (NP_004755) Hiwi2 (NP_689644), Hiwi3 (NP_001008496); Drosophila melanogaster (Dm) Agol (NP_72534I), Ago2 (NP_730054), Ago3 (ABO27430), Aubergine (CAA64320), PIWI (NP_476875); Arabidopsis thaliana (At) Agol (NP_849784), Ago2 (NP_1744I3), Ago3 (NP_1744I4), Ago4 (NP_565633), Ago5 (At2g27880), Ago6 (At2g32940), Ago7 (NP_I77l03), Ago8 (NP_197602), Ago9 (CAD66636), Agol0 (NP_199194); Shizosaccharomyces pombe (SP) Ago (NP_587782) and Caenorhabiditis elegans (Ce) Alg-I (NP_5I0322), Alg-2 (NP_87I992). Accession numbers are for GenBank. 
(a)

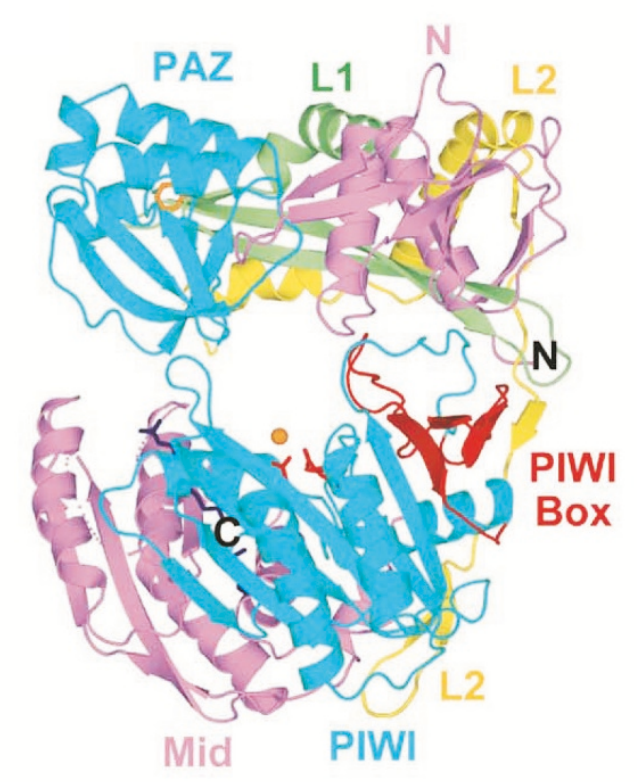

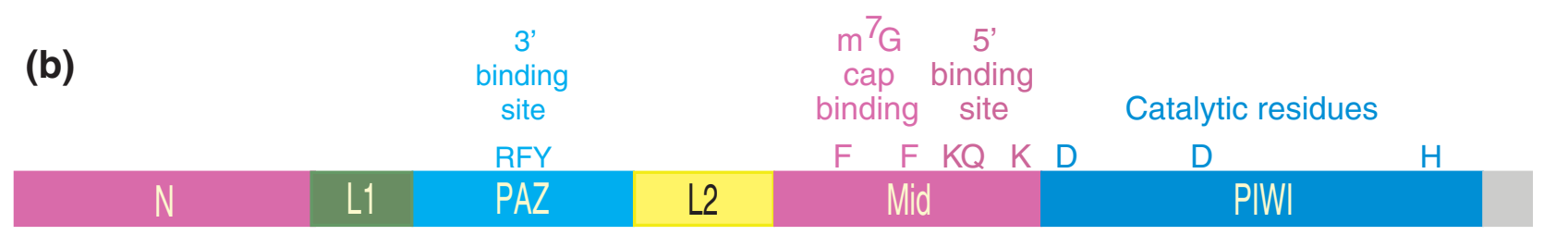

Figure 2

Structure of Argonaute proteins. (a) X-ray crystal structure of the Argonaute protein from the archaeon Aquifex aeolicus. The amino-terminal domain ( $N$, magenta) is linked by linker I (LI, green) to the PAZ domain (blue). Linker 2 (L2, yellow) connects the PAZ domain with the MID domain (magenta), which is followed by the PIWI domain (blue) at the carboxy-terminal end of the protein. The PIWI box (red) has been implicated in the interaction between Argonaute proteins and the nuclease Dicer in human cells [79]. (b) Schematic depiction of the human Ago2 protein. The domains are colored as in (a). In the PAZ domain, residues important for binding of small RNA 3' ends are indicated (R, arginine; F, phenylalanine; Y, tryptophan), and in the Mid domain, the residues required for $5^{\prime}$ end binding to small RNAs and binding to the 7-methylguanine ( $\left.\mathrm{m}^{7} \mathrm{G}\right)$ cap of target $\mathrm{mRNAs}$ are shown

(K, lysine; Q, glutamine) and the PIWI domain in red (catalytic residues are shown). (a) Reproduced with permission from [15].

mammals have shown that some are endonucleases, and these are often referred to as 'slicers'. In humans, only Ago2 has slicer activity, and a catalytic triad consisting of Asp597, Asp669 and His807 has been identified in this protein [13,14,17,18]. In Drosophila, both Ago1 and Ago2 are slicers; Ago1 can mediate miRNA-guided cleavage of RNA, whereas for Ago2, cleavage activity is predominantly guided by siRNAs. In A. thaliana, which has ten Argonaute genes, Ago1 has been identified as a slicer that uses both miRNAs and siRNAs as guides $[19,20]$. A. thaliana Ago4 can also act as a slicer, and has both catalytic and non-catalytic functions [21]. Interestingly, many Argonaute proteins are endonucleolytically inactive although the catalytic residues are conserved (Figure 1). Therefore, one could speculate that other factors, such as post-translational modifications, might contribute to slicer activity.
Additional structurally and functionally important motifs have recently been identified in Ago proteins (Figure 2b). Structural analysis of the sole Ago protein in the archaeon Archaeoglobus fulgidus revealed a third functionally important domain that resides between the PAZ and PIWI domains and is termed the MID domain. This domain binds the characteristic 5' phosphates of small RNAs and thus anchors small RNAs onto the Ago protein $[22,23]$. Furthermore, the MID domain has been implicated in proteinprotein interactions: Ago interactors such as Tas3 in S. pombe form a so-called 'Ago hook' that binds the MID domain of Ago proteins [24]. Whether binding of protein interactors and small RNAs occurs simultaneously or is mutually exclusive remains unclear. Finally, Ago proteins contain a highly conserved motif similar to the 7-methylguanine $\left(\mathrm{m}^{7} \mathrm{G}\right)$ cap-binding motif of eukaryotic translational 

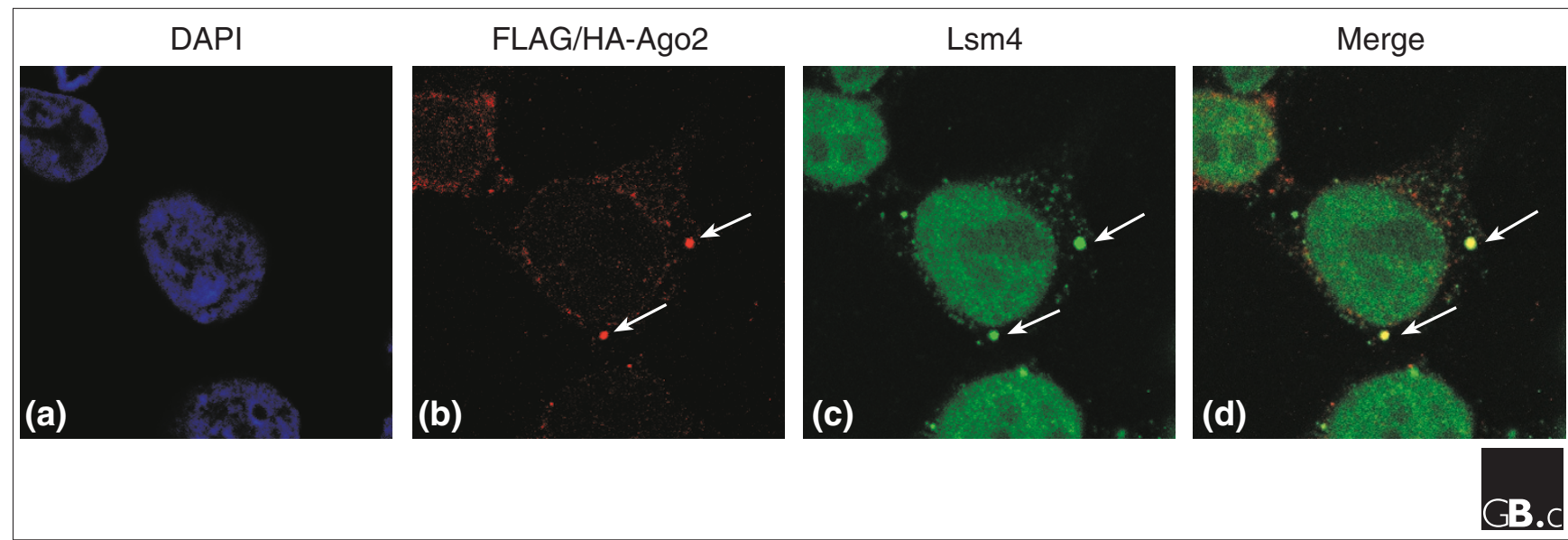

Figure 3

Ago proteins localize to cytoplasmic P-bodies. Human embryonic kindey cells (HEK 293T) were transfected with epitope-tagged Ago2

(FLAG/HA-Ago2). (a) Cells stained with DAPI to show the DNA. (b,c) The same cells stained with antibodies against (b) hemagglutinin (HA) and (c) Lsm4, a P-body marker involved in mRNA turnover. P-bodies are indicated by arrows. (d) Merged images from (b) and (c).

initiation factor $4 \mathrm{E}(\mathrm{eIF} 4 \mathrm{E})$ [25]. Two aromatic residues in human Ag02, Phe470 and Phe505, are required for this interaction. As some Ago proteins inhibit translational initiation of specific mRNA targets, it has been suggested that $\mathrm{m}^{7 \mathrm{G}-c a p}$ binding by Ago proteins may prevent eIF4E binding and therefore repress translation.

\section{Localization and function}

\section{Tissue distribution and subcellular localization}

Ago proteins localize to the cytoplasm of somatic cells and are concentrated in cytoplasmic processing bodies (P-bodies; Figure 3) [26-28]. P-bodies are highly dynamic and morphologically diverse foci where enzymes important for RNA turnover are enriched [29]. It has therefore been suggested that Ago proteins target mRNAs to P-bodies for degradation or translational repression. However, this model has been challenged recently. In Drosophila, Ago proteins can repress target mRNAs in the absence of P-bodies, and P-bodies are formed as a consequence of Ago function [30]. Moreover, a quantitative analysis in mammalian cells has shown that Ago2 also localizes to the diffuse cytoplasm as well as to stress granules - structures that are induced upon cellular stress and contain mRNA-protein complexes [31]. It is currently unclear which of these structures are essential for Ago function.

Drosophila germ cells are characterized by an electrondense, cytoplasmic structure called nuage, which is implicated in RNA interference (RNAi) and RNA processing and transport, and which contains the proteins Piwi and Aubergine (Aub), a member of the Piwi subfamily. Similar structures have been identified in mammalian germ cells and are called chromatoid bodies [32]. Interestingly, chromatoid bodies contain members of the Piwi as well as the Ago subfamilies and might therefore be the germ-cell counterparts of somatic-cell P-bodies [33,34].

Argonaute proteins have also been found in the nucleus. It is well established in plants that Ago4 directs siRNA-guided DNA methylation of chromatin [21,35,36]. Recently, it has been found that $A$. thaliana Ago4 (AtAgo4) localizes to distinct nuclear foci that are associated with the nucleolus and termed Cajal bodies. Cajal bodies are nuclear sites of ribonucleoprotein particle (RNP) assembly and it has been suggested that a larger DNA methylation complex containing AtAgo4, siRNAs and, presumably, many other factors is assembled in the Cajal bodies [37,38]. In Drosophila, Piwi and Aub have been implicated in the silencing of transcription. Although it has not yet been shown directly, it is very likely that Piwi and Aub localize to the nucleus of Drosophila germ cells. In human cells, Ago1 and Ago2 have also been implicated in transcriptional silencing. siRNAs directed against promoters of different genes associate with Ago1 and Ago2 and silence gene expression at the transcriptional level [39,40]. However, Ago proteins have not been clearly observed in mammalian cells by immunofluorescence studies, presumably due to the lack of highly sensitive antibodies.

\section{Functions of Argonaute proteins}

Members of the Argonaute protein family have been implicated in both transcriptional and post-transcriptional gene silencing. Ago proteins can bind siRNAs as well as miRNAs and mediate repression of specific target RNAs either by RNA degradation or by inhibiting translation. In mammals, miRNAs or siRNAs guide the RNA-induced silencing complex (RISC) to perfectly complementary target sites in mRNAs, where endonucleolytically active Ago proteins cleave the RNA (Figure 4) [41-46]. 
(a) siRNA precursor

\section{(b) miRNA precursor}

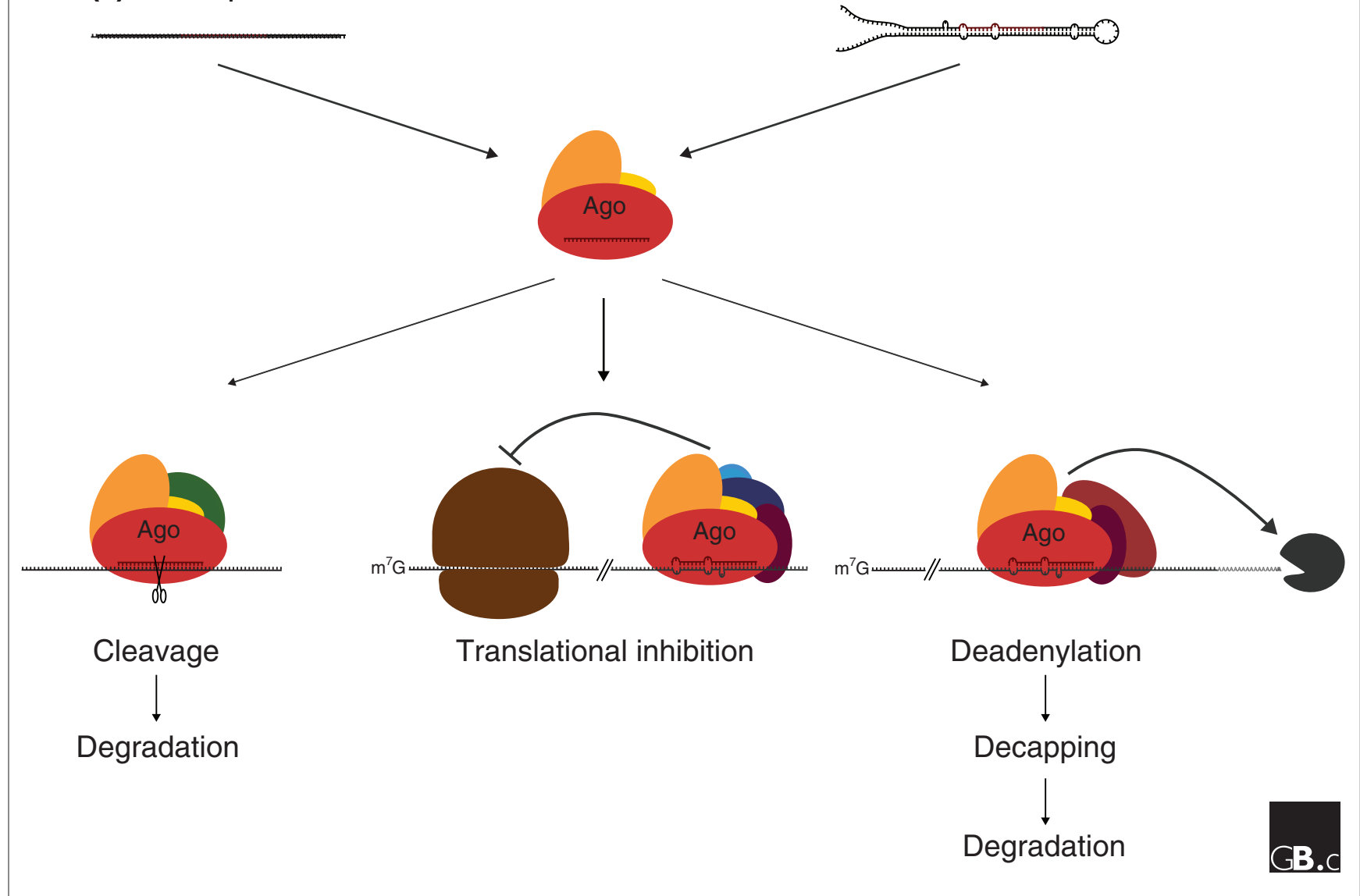

Figure 4

Roles of Argonaute proteins in gene silencing guided by small RNAs. Ago proteins can bind (a) siRNAs derived from long double-stranded precursor RNAs or (b) miRNAs derived from endogenous hairpin structures. On binding with perfect complementarity to a target mRNA, the Ago-siRNA or Ago-miRNA complex induces its cleavage and degradation (left). An Ago-miRNA complex binding imperfectly to the 3' UTR of the target mRNA induces translational inhibition (middle), or deadenylation and subsequent decapping and degradation of the target mRNA (right). $\mathrm{m}^{7} \mathrm{G}, 7$-methylguanine.

Other miRNAs, on the other hand, predominantly bind to partially complementary target sites located in the 3' untranslated regions (UTRs) of their specific target mRNAs. Imperfect base pairing between small RNAs and their target mRNAs leads to repression of translation and/or deadenylation (removal of the poly(A) tail) of the target, followed by destabilization of the target, which most probably occurs in P-bodies (Figure 4) $[47,48]$. The mechanism by which Ago proteins mediate translational repression is still a matter of debate. Ago proteins have been shown to act on translation initiation (summarized in [49]), on translation elongation [50-53] and on the degradation of nascent polypeptides [54]. Therefore, the mechanisms by which Ago proteins inhibit translation might depend on the target that is being regulated. Such a model, however, remains to be experimentally proven.

It was shown very recently that upon cell-cycle arrest in human cells, Ago proteins bind to the 3' UTRs of specific mRNAs and stimulate translation. Interestingly, Ago proteins inhibit translation in proliferating cells and it has therefore been suggested that Ago-mediated translational regulation oscillates between repression and activation during the cell cycle $[55,56]$.

In Drosophila, zebrafish and mammals, miRNAs can guide deadenylation of target mRNAs [57-59]. In Drosophila, it became apparent that the interaction of Ago proteins with GW182, a protein required for miRNA function, is required for efficient deadenylation and subsequent degradation of target mRNAs by providing an interaction platform for the CCR:NOT complex, the major deadenylase complex in fly cells [57]. Although members of the GW182 protein family are important for gene silencing in other organisms as well [26,60-62], their mode of action remains elusive.

In $S$. pombe, small RNAs are transcribed from centromeric repeats and associate with Ago to form the RNA-induced 
initiation of transcriptional gene silencing (RITS) complex. RITS recruits methyltransferases to specific genomic regions, leading to methylation of Lys9 in histone $\mathrm{H}_{3}$ and the subsequent establishment of silenced heterochromatin (reviewed in [63]). In Drosophila, Piwi and Aub have been reported to be required for binding of the heterochromatin-specific protein HP1 to heterochromatic regions [64,65]. Furthermore, Piwi, Aub and Ago3 (which belongs to the Drosophila Piwi subfamily) are required for transposon silencing in the Drosophila germ line [66-69]. Genetic studies revealed that Piwi is also required for germ-cell maintenance and it has recently been shown that Piwi has an additional role in epigenetic activation of distinct genomic loci [70]. The functions of the Piwi subfamily members in mammals are largely unknown. In mice, the Piwi subfamily members are MIWI, MIWI2, and MILI. Male MILI and MIWI knockout mice are sterile, implicating a role for MILI and MIWI in spermatogenesis [71,72]. MILI together with piRNAs has recently been shown to be involved in silencing of transposable elements in mouse testes [73,74].

\section{Frontiers}

Although the Argonaute protein family was discovered only recently, many of their cellular functions are known and some have been characterized in detail. Nevertheless, many aspects of Argonaute function are still unclear. For example, it is intriguing that only human Ago2 shows slicer activity, even though the catalytic residues are conserved in other human Ago proteins. The answer to this question will probably have to await X-ray structures of human Ago proteins with their bound small RNAs, which have not yet been reported. The slicer activities of Argonaute proteins have not been analyzed in a wide range of organisms, and most of the natural slicer targets have not been found. Ago proteins are embedded in large regulatory networks [75] and future research will aim to describe and functionally characterize such networks. It will be very interesting to analyze how Ago regulatory networks are regulated themselves, as Ago proteins have been implicated in a variety of diseases, including fragile $\mathrm{X}$ syndrome [76], autoimmune diseases [77] and cancer [78]. FMRp, the gene product affected in fragile $\mathrm{X}$ syndrome, has been found in biochemically purified Ago complexes and it has been suggested that FMRp is involved in miRNA biogenesis [76]. Autoimmune antibodies directed against Ago proteins and other components of the RNAi pathway have been isolated from patients suffering from systemic rheumatic diseases. It is therefore tempting to speculate that larger Ago complexes are targeted by the immune system and that Ago proteins might contribute to the establishment of autoimmune diseases [77]. Therefore, a detailed characterization of the biological roles of Ago proteins in conjunction with their associated small RNAs will not only help us to understand gene-silencing mechanisms but might also lead to a better understanding of numerous diseases.

\section{Acknowledgements}

We are grateful to $M$ Beitzinger and $L$ Weinmann for comments on the manuscript. Our research is supported by the Max Planck Society, the Deutsche Forschungsgemeinschaft (DFG, Me2064/2-I), the Deutsche Krebshilfe and the European Union (LSHG-CT-2006- 037900).

\section{References}

I. Bohmert K, Camus I, Bellini C, Bouchez D, Caboche M, Benning C: AGOI defines a novel locus of Arabidopsis controlling leaf development. $E M B O$ / 1998, I7:170-180.

2. Carmell MA, Xuan Z, Zhang MQ, Hannon GJ: The Argonaute family: tentacles that reach into RNAi, developmental control, stem cell maintenance, and tumorigenesis. Genes Dev 2002, 16:2733-2742.

3. Meister G, Tuschl T: Mechanisms of gene silencing by doublestranded RNA. Nature 2004, 431:343-349.

4. Hutvagner G, Simard MJ: Argonaute proteins: key players in RNA silencing. Nat Rev Mol Cell Biol 2007, 9:22-32.

5. Peters L, Meister G: Argonaute proteins: mediators of RNA silencing. Mol Cell 2007, 26:6 I I-623.

6. Sigova A, Rhind N, Zamore PD: A single Argonaute protein mediates both transcriptional and posttranscriptional silencing in Schizosaccharomyces pombe. Genes Dev 2004, 189:2359-2367.

7. Lingel A, Simon B, Izaurralde E, Sattler M: Structure and nucleic-acid binding of the Drosophila Argonaute 2 PAZ domain. Nature 2003. 426:465-469.

8. Lingel A, Simon B, Izaurralde E, Sattler M: Nucleic acid 3'-end recognition by the Argonaute2 PAZ domain. Nat Struct Mol Biol 2004, I I:576-577.

9. Ma JB, Ye K, Patel DJ: Structural basis for overhang-specific small interfering RNA recognition by the PAZ domain. Nature 2004, 429:3 18-322.

10. Song JJ, Liu J, Tolia NH, Schneiderman J, Smith SK, Martienssen RA, Hannon G], Joshua-Tor L: The crystal structure of the Argonaute2 PAZ domain reveals an RNA-binding motif in RNAi effector complexes. Nat Struct Biol 2003, 10:1026-1032.

II. Yan KS, Yan S, Farooq A, Han A, Zeng L, Zhou MM: Structure and conserved RNA binding of the PAZ domain. Nature 2003, 426: 468-474.

12. Rashid UJ, Paterok D, Koglin A, Gohlke H, Piehler J, Chen JC: Structure of Aquifex aeolicus argonaute highlights conformational flexibility of the PAZ domain as a potential regulator of RNA-induced silencing complex function. J Biol Chem 2007, 282: I 3824-I 3832.

13. Rivas FV, Tolia NH, Song JJ, Aragon JP, Liu J, Hannon GJ, Joshua-Tor L: Purified Argonaute2 and an siRNA form recombinant human RISC. Nat Struct Mol Biol 2005, 12:340-349.

14. Song JJ, Smith SK, Hannon GJ, Joshua-Tor L: Crystal structure of Argonaute and its implications for RISC slicer activity. Science 2004, 305: | 434- 1437

I5. Yuan YR, Pei Y, Ma JB, Kuryavyi V, Zhadina M, Meister G, Chen HY, Dauter Z, Tuschl T, Patel DJ: Crystal structure of $\boldsymbol{A}$. aeolicus Argonaute, a site-specific DNA guided endoribonuclease, provides insights into RISC-mediated mRNA cleavage. Mol Cell 2005, 19:405-4I9.

16. Parker JS, Roe SM, Barford D: Crystal structure of a PIWI protein suggests mechanisms for siRNA recognition and slicer activity. EMBO J 2004, 23:4727-4737.

17. Liu J, Carmell MA, Rivas FV, Marsden CG, Thomson JM, Song J, Hammond SM, Joshua-Tor L, Hannon GJ: Argonaute2 is the catalytic engine of mammalian RNAi. Science 2004, 305: |437- |44|.

18. Meister G, Landthaler M, Patkaniowska A, Dorsett Y, Teng G, Tuschl T: Human Argonaute2 mediates RNA cleavage targeted by miRNAs and siRNAs. Mol Cell 2004, I5:185-197.

19. Baumberger N, Baulcombe DC: Arabidopsis ARGONAUTEI is an RNA Slicer that selectively recruits microRNAs and short interfering RNAs. Proc Natl Acad Sci USA 2005, 102: I 1928 - I 1933.

20. Qi Y, Denli AM, Hannon G]: Biochemical specialization within Arabidopsis RNA silencing pathways. Mol Cell 2005, 19:421-428.

21. Qi Y, He X, Wang XJ, Kohany O, Jurka J, Hannon GJ: Distinct catalytic and noncatalytic roles of ARGONAUTE4 in RNA-directed DNA methylation. Nature 2006, 443: I008-10I2.

22. Ma JB, Yuan YR, Meister G, Pei Y, Tuschl T, Patel DJ: Structural basis for 5'-endspecific recognition of guide RNA by the $A$. fulgidus Piwi protein. Nature 2005, 434:666-670.

23. Parker JS, Roe SM, Barford D: Structural insights into mRNA recognition from a PIWI domain-siRNA guide complex. Nature 2005, 434:663-666. 
24. Till S, Lejeune E, Thermann R, Bortfeld M, Hothorn M, Enderle D, Heinrich C, Hentze MW, Ladurner AG: A conserved motif in Argonaute-interacting proteins mediates functional interactions through the Argonaute PIWI domain. Nat Struct Mol Biol 2007, 14:897-903.

25. Kiriakidou M, Tan GS, Lamprinaki S, De Planell-Saguer M, Nelson PT, Mourelatos Z: An mRNA m(7)G cap binding-like motif within human Ago2 represses translation. Cell 2007, |29:I|4|-II5I.

26. Jakymiw A, Lian S, Eystathioy T, Li S, Satoh M, Hamel JC, Fritzler MJ, Chan EK: Disruption of GW bodies impairs mammalian RNA interference. Nat Cell Biol 2005, 7:I267-1274.

27. Liu J, Valencia-Sanchez MA, Hannon GJ, Parker R: MicroRNA-dependent localization of targeted mRNAs to mammalian P-bodies. Nat Cell Biol 2005, 7:719-723.

28. Sen GL, Blau HM: Argonaute 2/RISC resides in sites of mammalian mRNA decay known as cytoplasmic bodies. Nat Cell Biol 2005, 7:633-636.

29. Eulalio A, Behm-Ansmant I, Izaurralde E: P bodies: at the crossroads of posttranscriptional pathways. Nat Rev Mol Cell Biol 2007, 8:9-22.

30. Eulalio A, Behm-Ansmant I, Schweizer D, Izaurralde E: P-body formation is a consequence, not the cause, of RNA-mediated gene silencing. Mol Cell Biol 2007, 27:3970-398I.

31. Leung AK, Calabrese JM, Sharp PA: Quantitative analysis of Argonaute protein reveals microRNA-dependent localization to stress granules. Proc Natl Acad Sci USA 2006, 103: I8I25-18130.

32. Kotaja N, Sassone-Corsi P: The chromatoid body: a germ-cell-specific RNA processing centre. Nat Rev Mol Cell Biol 2007, 8:85-90.

33. Kotaja N, Bhattacharyya SN, Jaskiewicz L, Kimmins S, Parvinen M, Filipowicz W, Sassone-Corsi P: The chromatoid body of male germ cells: similarity with processing bodies and presence of Dicer and microRNA pathway components. Proc Natl Acad Sci USA 2006, 103:2647-2652.

34. Kotaja N, Lin H, Parvinen M, Sassone-Corsi P: Interplay of PIWI/Argonaute protein MIWI and kinesin KIFI7b in chromatoid bodies of male germ cells. J Cell Sci 2006, I 19:2819-2825.

35. Zilberman D, Cao X, Jacobsen SE: ARGONAUTE4 control of locusspecific siRNA accumulation and DNA and histone methylation. Science 2003, 299:716-719.

36. Zilberman D, Cao X, Johansen LK, Xie Z, Carrington JC, Jacobsen SE: Role of Arabidopsis ARGONAUTE4 in RNA-directed DNA methylation triggered by inverted repeats. Curr Biol 2004, 14:12 I4 1220.

37. Li CF, Pontes O, El-Shami M, Henderson IR, Bernatavichute YV, Chan SW, Lagrange T, Pikaard CS, Jacobsen SE: An ARGONAUTE4-containing nuclear processing center colocalized with Cajal bodies in Arabidopsis thaliana. Cell 2006, 126:93-106.

38. Pontes O, Li CF, Nunes PC, Haag J, Ream T, Vitins A, Jacobsen SE, Pikaard CS: The Arabidopsis chromatin-modifying nuclear siRNA pathway involves a nucleolar RNA processing center. Cell 2006 126:79-92.

39. Janowski BA, Huffman KE, Schwartz JC, Ram R, Nordsell R, Shames DS, Minna JD, Corey DR: Involvement of AGOI and AGO2 in mammalian transcriptional silencing. Nat Struct Mol Biol 2006, I3:787792.

40. Kim DH, Villeneuve LM, Morris KV, Rossi J]: Argonaute-I directs siRNA-mediated transcriptional gene silencing in human cells. Nat Struct Mol Biol 2006, 13:793-797.

4I. Haley B, Zamore PD: Kinetic analysis of the RNAi enzyme complex. Nat Struct Mol Biol 2004, I I:599-606.

42. Hammond SM, Bernstein E, Beach D, Hannon G]: An RNA-directed nuclease mediates post-transcriptional gene silencing in Drosophila cells. Nature 2000, 404:293-296.

43. Hammond SM, Boettcher S, Caudy AA, Kobayashi R, Hannon G]: Argonaute2, a link between genetic and biochemical analyses of RNAi. Science 2001, 293: I I 46-II I50.

44. Hutvágner G, Zamore PD: A microRNA in a multiple-turnover RNAi enzyme complex. Science 2002, 297:2056-2060.

45. Martinez J, Patkaniowska A, Urlaub H, Lührmann R, Tuschl T: Singlestranded antisense siRNAs guide target RNA cleavage in RNAi. Cell 2002, II 0:563-574.

46. Martinez J, Tuschl T: RISC is a 5' phosphomonoester-producing RNA endonuclease. Genes Dev 2004, 18:975-980.

47. Chen PY, Meister G: microRNA-guided posttranscriptional gene regulation. Biol Chem 2005, 386: I 205-I218.

48. Pillai RS, Bhattacharyya SN, Filipowicz W: Repression of protein synthesis by miRNAs: how many mechanisms? Trends Cell Biol 2007 I7: I |8-126.
49. Meister G: miRNAs get an early start on translational silencing. Cell 2007, I3I:25-28.

50. Maroney PA, Yu Y, Fisher J, Nilsen TW: Evidence that microRNAs are associated with translating messenger RNAs in human cells. Nat Struct Mol Biol 2006, I3: I I02-I I 07.

5I. Olsen $\mathrm{PH}$, Ambros $\mathrm{V}$ : The lin-4 regulatory RNA controls developmental timing in Caenorhabditis elegans by blocking LIN-I4 protein synthesis after the initiation of translation. Dev Biol 1999, 216:671680.

52. Petersen CP, Bordeleau ME, Pelletier J, Sharp PA: Short RNAs repress translation after initiation in mammalian cells. Mol Cell 2006, 21:533-542.

53. Seggerson K, Tang L, Moss EG: Two genetic circuits repress the Caenorhabditis elegans heterochronic gene lin-28 after translation initiation. Dev Biol 2002, 243:2 I 5-225.

54. Nottrott S, Simard MJ, Richter JD: Human let-7a miRNA blocks protein production on actively translating polyribosomes. Nat Struct Mol Biol 2006, 13: I I 08-I I I4.

55. Vasudevan S, Steitz JA: AU-rich-element-mediated upregulation of translation by FXRI and Argonaute 2. Cell 2007, I28: I I05-I I I8.

56. Vasudevan $\mathrm{S}$, Tong $\mathrm{Y}$, Steitz JA: Switching from repression to activation: microRNAs can up-regulate translation. Science 2007, 318:1931-1934.

57. Behm-Ansmant I, Rehwinkel J, Doerks T, Stark A, Bork P, Izaurralde E: mRNA degradation by miRNAs and GWI82 requires both CCR4:NOT deadenylase and DCPI:DCP2 decapping complexes. Genes Dev 2006, 20:1885-1898.

58. Giraldez AJ, Mishima Y, Rihel J, Grocock RJ, Van Dongen S, Inoue K, Enright AJ, Schier AF: Zebrafish MiR-430 promotes deadenylation and clearance of maternal mRNAs. Science 2006, 3I2:75-79.

59. Wu L, Fan J, Belasco JG: MicroRNAs direct rapid deadenylation of mRNA. Proc Natl Acad Sci USA 2006, 103:4034-4039.

60. Ding L, Spencer A, Morita K, Han M: The developmental timing regulator AIN-I interacts with miRISCs and may target the argonaute protein ALG-I to cytoplasmic P bodies in C. elegans. Mol Cell 2005, 19:437-447.

6I. Liu J, Rivas FV, Wohlschlegel J, Yates JR, 3rd, Parker R, Hannon GJ: A role for the P-body component GWI82 in microRNA function. Nat Cell Biol 2005, 7: I I6I-I I66.

62. Meister G, Landthaler M, Peters L, Chen PY, Urlaub H, Luhrmann R, Tuschl T: Identification of novel argonaute-associated proteins. Curr Biol 2005, 15:2 I 49-2I 55.

63. Lippman Z, Martienssen R: The role of RNA interference in heterochromatic silencing. Nature 2004, 431:364-370.

64. Pal-Bhadra M, Leibovitch BA, Gandhi SG, Rao M, Bhadra U, Birchler JA, Elgin SC: Heterochromatic silencing and HPI localization in Drosophila are dependent on the RNAi machinery. Science 2004, 303:669-672.

65. Brower-Toland B, Findley SD, Jiang L, Liu L, Yin H, Dus M, Zhou P, Elgin SC, LinH: Drosophila PIWI associates with chromatin and interacts directly with HPIa. Genes Dev 2007, 21:2300-23II.

66. Aravin AA, Klenov MS, Vagin VV, Bantignies F, Cavalli G, Gvozdev VA: Dissection of a natural RNA silencing process in the Drosophila melanogaster germ line. Mol Cell Biol 2004, 24:6742-6750.

67. Brennecke J, Aravin AA, Stark A, Dus M, Kellis M, Sachidanandam R, Hannon GJ: Discrete small RNA-generating loci as master regulators of transposon activity in Drosophila. Cell 2007, 128:1089-I I03.

68. Kalmykova Al, Klenov MS, Gvozdev VA: Argonaute protein PIWI controls mobilization of retrotransposons in the Drosophila male germline. Nucleic Acids Res 2005, 33:2052-2059.

69. Vagin VV, Sigova A, Li C, Seitz H, Gvozdev V, Zamore PD: A distinct small RNA pathway silences selfish genetic elements in the germline. Science 2006, 313:320-324.

70. Yin H, Lin H: An epigenetic activation role of Piwi and a Piwi-associated piRNA in Drosophila melanogaster. Nature 2007, 450:304-308.

7I. Deng W, Lin H: miwi, a murine homolog of piwi, encodes a cytoplasmic protein essential for spermatogenesis. Dev Cell 2002, 2:819-830.

72. Kuramochi-Miyagawa S, Kimura T, Ijiri TW, Isobe T, Asada N, Fujita Y, Ikawa M, Iwai N, Okabe M, Deng W, Lin H, Matsuda Y, Nakano T: Mili, a mammalian member of piwi family gene, is essential for spermatogenesis. Development 2004, I31:839-849.

73. Aravin A, Gaidatzis D, Pfeffer S, Lagos-Quintana $M$, Landgraf $P$, lovino N, Morris P, Brownstein MJ, Kuramochi-Miyagawa S, Nakano T, Chien M, Russo JJ, Ju J, Sheridan R, Sander C, Zavolan M, Tuschl T: A novel class of small RNAs bind to MILI protein in mouse testes. Nature 2006, 442:203-207. 
74. Aravin AA, Sachidanandam R, Girard A, Fejes-Toth K, Hannon GJ: Developmentally regulated piRNA clusters implicate MILI in transposon control. Science 2007, 316:744-747.

75. Höck J, Weinmann L, Ender C, Rüdel S, Kremmer E, Raabe M, Urlaub $\mathrm{H}$, Meister G: Proteomic and functional analysis of Argonaute-containing mRNA-protein complexes in human cells. EMBO $\operatorname{Rep} 2007,8: 1052-1060$.

76. Jin P, Zarnescu DC, Ceman S, Nakamoto M, Mowrey J, Jongens TA, Nelson DL, Moses K, Warren ST: Biochemical and genetic interaction between the fragile $X$ mental retardation protein and the microRNA pathway. Nat Neurosci 2004, 7: I I3-I 17.

77. Jakymiw A, Ikeda K, Fritzler MJ, Reeves WH, Satoh M, Chan EK: Autoimmune targeting of key components of RNA interference. Arthritis Res Ther 2006, 8:R87.

78. Taubert H, Greither T, Kaushal D, Würl P, Bache M, Bartel F, Kehlen A, Lautenschläger C, Harris L, Kraemer K, Meye A, Kappler M, Schmidt H, Holzhausen HJ, Hauptmann S: Expression of the stem cell self-renewal gene Hiwi and risk of tumour-related death in patients with soft-tissue sarcoma. Oncogene 2007, 26:1098-1 100 .

79. Tahbaz N, Kolb FA, Zhang H, Jaronczyk K, Filipowicz W, Hobman TC: Characterization of the interactions between mammalian PAZ PIWI domain proteins and Dicer. EMBO Rep 2004, 5: 189-194.

80. Sasaki T, Shiohama A, Minoshima S, Shimizu N: Identification of eight members of the Argonaute family in the human genome. Genomics 2003, 82:323-330.

81. Williams RW, Rubin GM: ARGONAUTEI is required for efficient RNA interference in Drosophila embryos. Proc Natl Acad Sci USA 2002, 99:6889-6894.

82. Yigit E, Batista PJ, Bei Y, Pang KM, Chen CC, Tolia NH, Joshua-Tor L, Mitani S, Simard MJ, Mello CC: Analysis of the C. elegans Argonaute family reveals that distinct Argonautes act sequentially during RNAi. Cell 2006, 127:747-757.

83. Hunter C, Sun H, Poethig RS: The Arabidopsis heterochronic gene ZIPPY is an ARGONAUTE family member. Curr Biol 2003, 13:17341739. 